\title{
Effect of Psychological Contract Fulfillment, Employee's Job Satisfaction on Organizational Performance: Evidence from Ghana
}

\author{
Zeliat Badmus Suleman ${ }^{1}$, Zhao Xiuli ${ }^{1} \&$ Shaibu Ali $^{2}$ \\ ${ }^{1}$ School of Management, Jiangsu University, Zhenjiang 212013, People's Republic of China \\ ${ }^{2}$ School of Finance, Jiangsu University, Zhenjiang 212013, People's Republic of China \\ Correspondence: Zhao Xiuli, School of Management, Jiangsu University, Zhenjiang, 212013, PR China. E-mail: \\ 1000003765@ujs.edu.cn
}

Received: July 28, 2019

doi:10.5539/ijbm.v14n12p32
Accepted: September 22, 2019

Online Published: November 8, 2019

\begin{abstract}
This paper aimed at examining the effects of employees' psychological contract fulfillment, employees' job satisfaction on organizational performance from some selected companies on the Ghana Stock Exchange (GSE). Many Companies today have invested more into their organization to achieve Psychological Contract between them and their employees, and other important stakeholders of the company. Random sampling was used to select top employees from selected companies on the Ghana Stock Exchange. Structured questionnaires were used for the collection of data. Based on the analysis, the researcher realized that there is a significant positive relationship between psychological contract fulfillment and employee's job satisfaction. It also revealed that there is a significant positive relationship between psychological contract fulfillment and organizational performance. Finally, the research revealed that, there is a significant positive relationship between employee's job satisfaction and organizational performance.
\end{abstract}

Keywords: psychological contract fulfillment, employee's job satisfaction, organizational performance, Ghana

\section{Introduction}

The most valuable assets of an organization's is its workforce. An organizations success depends on its relationship with its employees. To develop this relationship, there should be a contract between the employers and employees. A contract is an agreement between two parties in which the parties involved are legally bound to perform certain duties. Pittino, Visintin, Lenger, and Sternad (2016), suggested that, research in Psychological contract is important when defining employees' interactions with their organizations and subsequent consequences, which includes work attitudes and employees outcome. Busser, Shulga, Kang, and Ramirez Molintas (2019) and Hotchkiss (2016), defined psychological contract as the promises (direct or indirect) two parties make to each another. An employee's promise to work diligently after he/she has been promised job security and subsequent training can be said to be an example. This contract is termed psychological because it portrays each party's thoughts of the relationship and promises involved. Muls et al. (2015), stated that the difference between psychological contract and legal contract is that, psychological contract is implicit.

Psychological Contract Fulfillment (PCF), according to Karagonlar et al. (2016), is defined as the degree to which an organization fulfills its duties to its workers, considering the well-being of the workers. Psychological contract is influenced by the social element theory the social exchange element, which results to positive employee behaviors. Rodwell et al. (2015), also found out in their work that, PCF is also known to increase trust among stakeholders, lower levels of emotional fatigue and stress, increase job satisfaction, improve employee's well-being, and organizational commitment. Employee satisfaction has become an essential corporate objective in recent years. Motivated and committed staff can be a determining factor in the success of an organization. Job satisfaction is known to be linked to how workers expectations of work are in congruence with their actual outcomes. Organizations cannot achieve their goals and aims if the employees do not feel satisfied. Employee job satisfaction is the thoughts and feelings employees have towards their joblwork which motivate them to put up the best in performing their duties. Stamolampros, Korfiatis, Chalvatzis, and Buhalis (2019), proposed in their work that, for an organization to achieve its goals, it needs to understand what employees expect and must pay attention to fulfilling their expectations to fulfill organization's side of the contract. Psychologically written agreement (contract) makes employee's satified on their jobs. In the recent past, many scholars have investigated 
the area of employee psychological contract on job satisfaction. Nguyen, Lu, Hill, and Conduit (2019), found the understanding of psychological contracts to yield significant increase in employee's job outcome and their satisfaction. Organizational performance is defined as the process of comparing organizational goals to its objectives. When analyzing organizational performance, certain factors have to be considered, which include primary outcomes, market performance, shareholder value performance, and production capacity performance. Gurd and Helliar (2017), suggested that organizational output and competence can only be achieved when all the needs of employees both physiological and socio-emotional needs are satisfied.

However, the effect of employee psychological contract fulfillment on job satisfaction and organizational performance has not been examined thoroughly, and it appears that there is limited literature in that area of study. Therefore, the main aim of this paper is to bridge that gap by exploring the effect of employee psychological contract fulfillment on job satisfaction and organizational performance in some selected organizations in Ghana.

\section{Literature and Hypotheses Development}

\subsection{Employees Psychological Contract Fulfillment and Its Relationship with Employee's Job Satisfaction}

According to Chen, Leung, and Evans (2016), job satisfaction refers to the attitude and feelings people develop about their work. He also explained that positive attitudes lead to higher job satisfaction and negative attitude leads to a lower level of job satisfaction. When workers are satisfied with their job, they show Confident and encouraging attitudes towards their job. On the other hand, dissatisfied workers will show undesirable and disapproving attitudes towards their job. According to Krausert (2017), he explained in his work that, a strong positive association exists between an individual worker's emotions and the job he/she provides (productivity). Coetzee and Stoltz (2015), also suggested that breach of the contract as obliged by the employer for services rendered such as salaries and promotions subsequently lead to reduction in productivity. A psychological contract is said to be based on the rule of reciprocity, and it can be incidental that an employee will reciprocate fulfilled promises with loyalty or lower turnover intentions.

Theory on breach of psychological contract as stated by Spasojevic, Lohmann, and Scott (2019) in the context of organizational leadership, confirms that when an employee observes an unfavorable change in the promises made between the employee and the organization, less work is done on their part (productivity) with an increase in absenteeism and turnover. When this happens such employees may engage in behavior such as destructive rumors, thievery and rendering of poor services that are counter-productive. These counter-productive conducts subsequently causes financial loss to the organization (loss of productivity and replacement cost). Dogru, McGinley, Line, and Szende (2019), in his study found out that job satisfaction is subjective to series of factors and these factors include the type of work, income improvement opportunities, management, psychological contract, workgroup,and work conditions. Li and Wu (2018), explained in their study that, employees who are known to be dissatisfied mostly suffer depression, anxiety, fatigue, restless sleep pattern and muscle and joint stiffness. These significantly affect the psychological and physical health of the employees which subsequently lead to indirect financial loses to the organization as employee performance decreases. Turnea (2018), stated in his work that, Psychological Contract theory explained that employees who are family men/women and medical insurance might agree on contracts that have causes that benefit their families like flexible work hours. Among the 160 managers examined in a cross-sectional study, results reveal higher levels of job satisfaction on perceived psychological contract fulfillment. Nishanthi and Mahalekemge (2016) used 50 executive level employees in an apparel company in Sri Lanka to investigate the impact of psychological contract on employees outcome of job satisfaction and organizational commitment. They found that there is a positive relationship between psychological contract and employee job satisfaction and organizational commitment. Based on the above assertion by other researchers, it is important to hypothesize that:

H1: Employees Psychological Contract Fulfillment has a direct positive relation with Employees Job satisfaction

\subsection{Employees Psychological Contract Fulfillment and Its Relation with Organizational Performance}

Liu, Lin, and Shu (2017), in his study, found out that, breaching of psychological contract affects job performance, job satisfaction, and employee's commitment. Huang, Huang, and Zhang (2019), also explained that a psychological contract has an effect on workers job outcomes, such as job satisfaction and employee commitment, which subsequently affects the performance of the organization. When a psychological contract is breached, it will affect employee's commitment and performance critically and will also lead subsequently to organizational failure. Organizations must therefore, improve the psychological contract fulfillment to its workers.

Arthur and kolson (2017), used a mixed method to collect data from 188 employees of Asanko gold mines to study psychological contract fulfillment and its implications on employee performance. The result shows that, strong 
psychological contract policy will help improve employee performance. Thus, when employees are motivated, they arrive to work early, work effectively, meet expected deadlines, increase productivity, etc.

However, organizational success or performance does not have direct rewards or benefits on employees. Vuori, Törnroos, Ruokolainen, and Wallin (2019) ; Durst, Moore, Ritter, and Barkema (2018), stated in their work that, HR policies helps to improve psychological contract that leads to increase in organizational performance. Psychological contract with HR practices and policies have been examined to have a positive relationship with organizational performance (Suh, Shim, \& Button, 2018). This implies that improved HR practices can lead to higher psychological contracts fulfillment, which will intend to bring out improved employee attitudes and will increased organizational performance (Adhikari, Choi, \& Sah, 2017). We, therefore, hypothesize that;

\section{H2: Employees Psychological Contract Fulfillment would have a positive effect on Organizational Performance}

\subsection{Employee's Job Satisfaction and Its Relationship with Organizational Performance}

Turnea (2018) and Bufquin, DiPietro, Orlowski, and Partlow (2017), in their study, found out that there is a positive correlation between job satisfaction and individual performances. According to Wang and Lang (2019), in his work, found out there is a positive association between job satisfaction and organizational performance. On the other hand, Ibrahim, Boerhannoeddin, and Kazeem Kayode (2017), did not find any statistically significant relationship between job satisfaction and organizational performance. Pittino et al. (2016), also examined in his research that companies with more satisfied workers tend to be more productive than companies with dissatisfied workers. Huang et al. (2019), found out that there are positive correlations between workers job satisfaction and organizational performance which were measured by productivity, profit, employee turnover, employee accidents, and customer satisfaction.

Falola et al. (2018), in their studies, suggested that, there is a positive relationship between job satisfaction and job performance, which increases organizational performance. Durst et al. (2018), suggested that, job satisfaction has a positive impact on organizational performance. Thus, when employees are satisfied with their job, they are motivated to perform better and their turnover intention is low. Bakotic (2016) conducted an empirical study on 40 large and medium sized Croatia companies to examine the relationship between job satisfaction and organizational performance. The study aimed to examine the connection between the two variables, the direction and the intensity of the relationship. The result of the study showed a clear connection between employee's job satisfaction and organizational performance in both directions. There was a strong connection between employee's job satisfaction and organizational performance but weak connection between organizational performance and employee's job satisfaction.

Oludayo, Akanbi, Obot, Popoola, and Atayero (2018), in their work, suggested that Employee satisfaction is a predictor of an organizations efficiency and performance. Salem and Abdien (2017), also examine the relationship between organizational performance and employee satisfaction and found a positive association between them. Carter, Dudley, Lyle, and Smith (2019), in their study to investigate employee job satisfaction and organizational performance found that, when conflicts are well managed in an organization, employees are encouraged to participate in decision-making and it is positively related to employee job satisfaction and organizational performance.

Initial studies have explained that employee's attitudes have a relationship with organizational performance outcomes and workers job satisfaction. Based on the above evidence and support of the relationship between the above variables, the following will be hypothesized:

\section{H3: Employee's job satisfaction will positively influence Organizational Performance}

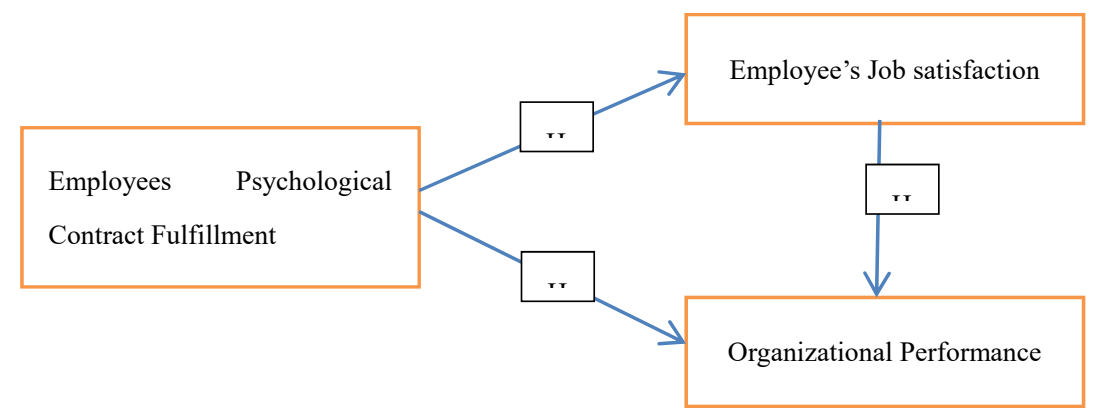

Figure1. Conceptual model and hypotheses of the study 


\section{Methodology}

The main objective of this study is to examine the effect of employee psychological contract fulfillment on job satisfaction and organizational performance in some selected organizations in Ghana. A random sampling method was use to select respondents from some selected companies on the Ghana Stock Exchange (GSE) in terms of population and business presence. Three hundred (300) participants were selected; however, 200 responses were received and were found to be useable after the initial screening and data cleaning. A Likert scale, ranging from $1=$ strongly disagree to $5=$ strongly agree was used. The questions were adapted from other researchers who used the questions in similar studies. The questionnaire was in three (3) parts. The first part has to do with the demographics; the second part had to do with the measurement of construct for the independent variable whiles the third part sought for the dependent variables.

The questionnaire consisted of closed-ended questions for the constructs, five-point Likert scales, and socio-demographic data. The scale for the measurement of job satisfaction was adopted from J. F. Hair, Risher, Sarstedt, and Ringle (2019), Lomax and Schumacker (2004), Schumacker (2017) whiles Henseler, Ringle, and Sarstedt (2015), proposed that for the measurement of psychological contract just as Hair Jr, Hult, Ringle, and Sarstedt (2016), did for the organizational performance measurement.

The data collected were analyzed through the help of SPSS version 22 and SmartPLS v. 3. Descriptive analysis was use for demographic variables, and hypotheses were tested using structural equation modeling (SEM) and Stata version 12. Content and construct validations were made. Confirmatory and Exploratory factor analysis was also used to purify the measures, assess the unidimensionality of the scale items, and assess discriminant validity among the constructs.

From the questionnaire, the following demographic data were collected for the study: gender, age, and level of education.

Table 1. Gender demographics of respondents

\begin{tabular}{llllll}
\hline & & Frequency & Percent & Valid Percent & Cumulative Percent \\
\hline Valid & Male & 132 & 66.3 & 66.3 & 66.3 \\
& Female & 67 & 33.7 & 33.7 & 100.0 \\
& Total & 199 & 100.0 & 100.0 & \\
\hline
\end{tabular}

Response from table 1 above shows that 132 respondents were males representing $66.3 \%$, and 67 respondents representing $33.7 \%$ are females. This means that majority of the respondents were males.

Table 2. Age demographics of respondents

\begin{tabular}{llllll}
\hline & Frequency & Percent & Valid Percent & Cumulative Percent \\
\hline \multirow{4}{*}{ Valid } & 18-25 years & 40 & 20.1 & 20.1 & 20.1 \\
& 26-33years & 96 & 48.2 & 48.2 & 68.3 \\
& 34-41years & 59 & 29.6 & 29.6 & 98.0 \\
& 42years and above & 4 & 2.0 & 2.0 & 100.0 \\
& & 199 & 100.0 & 100.0 & \\
\hline
\end{tabular}

The results of the study in the above table 2 shows that 40 respondents representing $20.1 \%$ were between the ages of "18-25 years"; 96 respondents representing $48.2 \%$ were between the ages of "26-33 years"; 59 respondents representing $29.6 \%$ were between the ages of " $34-41$ years" and 4respondents representing $2 . \%$ were "40 years and above".

This means that majority of the respondents were between the ages of $26-33$ years. Response from table 3 above, shows that 5 respondent represent $2.5 \%$ are from High School, 13 respondent represent $6.5 \%$ are doing diploma course, 56 respondent represent $28.1 \%$ are holders of first degree, 117 respondent represent $58.8 \%$ are graduate students, 8 respondent represent $4 \%$ are from other levels of Education. This means that majority of the respondents were graduate students. 
Table 3. Educational background of respondents

\begin{tabular}{llllll}
\hline & & Frequency & Percent & Valid Percent & Cumulative Percent \\
\hline \multirow{4}{*}{ Valid } & high school & 5 & 2.5 & 2.5 & 2.5 \\
& Diploma & 13 & 6.5 & 6.5 & 9.0 \\
& undergraduate & 56 & 28.1 & 28.1 & 37.2 \\
& Graduate & 117 & 58.8 & 58.8 & 96.0 \\
& Others & 8 & 4.0 & 4.0 & 100.0 \\
& Total & 199 & 100.0 & 100.0 & \\
\hline
\end{tabular}

\subsection{Measurement Model of Reliability and Validity}

Construct reliability weighs how consistent internal variables are and evaluated via item factor loading with an acceptable value of 0.70 and Cronbach's alpha with the acceptable level of 0.7(J. Hair, Ringle, \& Sarstedt, 2011; Ringle, Wende, \& Becker, 2015). Moreover, in Table 4, all the variables recorded Cronbach alpha levels beyond 0.70 ; this is to say that the measurement of each construct relies very much on these multiple measures. Construct validity assesses the level to which a measures symbolise and are associated with observed eventualities of the construct through the principal theory (Fornell \& Larcker, 1981a). This is evaluated through convergent validity and discriminant validity (Ringle et al., 2015). Convergent validity was considered adequate since the average variance extracted (AVEs) and composite reliability (CR) satisfied the minimum of 0.50 and 0.70 respectively (Fornell \& Larcker, 1981b; Ringle et al., 2015).

Table 4. Item loading and construct reliability

\begin{tabular}{llllll}
\hline ITEMS & FL & CA & rho_A & CR & AVE \\
\hline EPCF 1 & 0.795 & 0.842 & 0.844 & 0.888 & 0.613 \\
EPCF 2 & 0.813 & & & & \\
EPCF 3 & 0.749 & & & & \\
EPCF 4 & 0.784 & & & & \\
EPCF 5 & 0.774 & & & & \\
EJS 1 & 0.826 & 0.731 & 0.735 & 0.848 & 0.650 \\
EJS 2 & 0.804 & & & & \\
EJS 3 & 0.788 & & & & \\
OP 1 & 0.733 & 0.673 & 0.678 & 0.822 & 0.606 \\
OP 2 & 0.832 & & & & \\
OP 3 & 0.767 & & & & \\
\hline
\end{tabular}

Notes. EPCF - Employees Psychological Contract Fulfilment, EJS-Employee's Job Satisfaction, OP-Organizational Performance, FL-Item Loadings , CA-Cronbach's Alpha, CR-Composite Reliability, AVE-Average Variance Extracted.

Discriminant analysis requires a factor to correlate higher than with any other construct on its scale (Messick, 1988).

Table 5. Discriminant validity

\begin{tabular}{llll}
\hline & EJS & EPCF & OP \\
\hline EJS & $\underline{\mathbf{0 . 8 0 6}}$ & & \\
EPCF & 0.662 & $\underline{\mathbf{0 . 7 8 3}}$ & \\
OP & 0.515 & 0.394 & $\underline{\mathbf{0 . 7 7 9}}$ \\
\hline
\end{tabular}

Notes. EPCF - EJS - Employee's Job Satisfaction, Employees Psychological Contract Fulfillment, OP_Organizational Performance.

From table 5 above, it is clear that all the factors loaded higher than any other factor on their scales. Employees Job Satisfaction on its scale had a value of about 0.8 , which is higher than any other construct on that scale. Employees Psychological Contract Fulfillment has a value of (0.7) and OP (0.7).

\section{Empirical Results}

To determine the significance of t-statistics, regression weights, $t$-values and p-values were evaluated so as to simulate the structural model (Chin, 2010; Ringle et al., 2015). The results of the structural model for testing the 
research hypotheses are presented in Table 4.

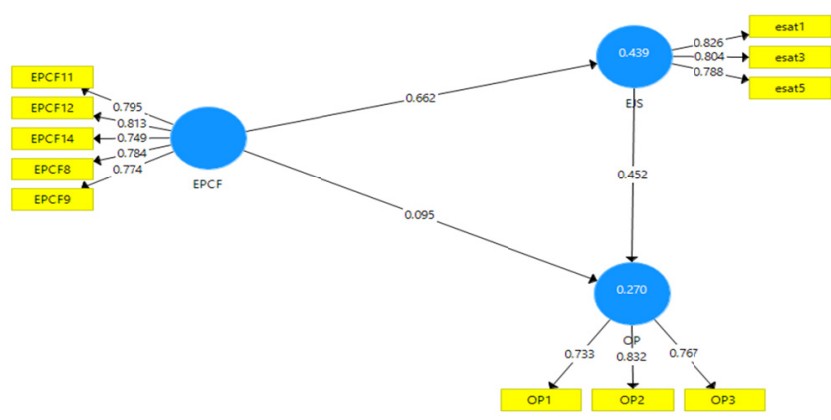

Figure 2. Path Analysis

\section{Result of Hypothesis}

We carried out a test of hypothesis on the effect of psychological contract fulfillment, Employee's Job Satisfaction and Organizational Performance using Smart PLS software. Three out of the three variables tested showed a positive and significant relationship with the dependent variable. In the first model, we tested the effect of psychological contract fulfillment on employee's job satisfaction. EJS $(\beta=0.234 ; \mathrm{t}=7.21 ; \mathrm{p}<0.000)$ and this led to the acceptance of H1. This means that the effect of psychological contract fulfillment has a greater effect on employee's job satisfaction. In addition, the Beta shows that when the effect of psychological contract fulfillment increase by $1 \%$ employee's job satisfaction increases by $23.4 \%$. Thus the more employers fulfill their side of the contract; employees will be satisfied and performed better on the job.

Table 6. Hypothesis testing

\begin{tabular}{llllll}
\hline Hypothesis & & Beta & T-value & P-Value & Action \\
\hline H1 & EPCF $\rightarrow$ EJS & 0.234 & 7.21 & 0.000 & Accepted \\
H2 & EPCF $\rightarrow$ OP & 0.167 & 2.29 & 0.024 & Accepted \\
H3 & EJS $\rightarrow$ OP & 0.884 & 7.22 & 0.000 & Accepted \\
\hline
\end{tabular}

Notes. EPCF - EJS - Employee's Job Satisfaction, Employees Psychological Contract Fulfillment, OP-Organizational Performance.

This finding supports earlier findings by Nishanthi and Mahalekemge (2016) and Brikend (2011).

Furthermore, we tested the effect of psychological contract fulfillment on Organizational Performance. OP $(\beta=$ $0.167 ; \mathrm{t}=2.29 ; \mathrm{p}<0.024)$ and this led to the acceptance of $\mathrm{H} 2$. This means that the effect of psychological contract fulfillment has a greater effect on Organizational Performance. In addition, the Beta shows that when the effect of psychological contract fulfillment increase by $1 \%$ on Organizational Performance increases by $16.7 \%$. Thus the more employers fulfill their side of the contract, employees will be satisfied, and they will work well to achieve the organizational objective. This finding supports earlier findings by Arthur and Kolson (2017) and Yalabik (2014).

Finally, the effect of employee's job satisfaction on organizational performance was also tested. OP ( $\beta=0.884 ; \mathrm{t}=$ $7.22 ; \mathrm{p}<0.000)$ and this led to the acceptance of H3. This means that the effect of employee's job satisfaction has a greater effect on Organizational Performance. In addition, the Beta shows that when the effect of psychological contract fulfillment increases by $1 \%$ on Organizational Performance increases by $88.4 \%$. Thus the more employees are happy and satisfied with their job, the more the organization will achieve its stated objective thus (Performance). This finding supports earlier findings by Latif et al., (2013) and Bakotic (2016).

\section{Discussion}

This study has reviewed a lot of theoretical implications due to the little research done on psychological contract fulfillment in Ghana. The purpose of this study is to examine the outcome of psychological contract fulfillment, employees' job satisfaction on organizational performance, and this relationship has been positively established. The study revealed that when an employer or organization manages psychological contract fulfillment between 
them and their employees or staffs, thus pay attention to fulfilling the organization's side of the contract. Paying the agreed salary, insurance, and so on, the employee tends to be happy and make sure he/she will work with his whole heart leading to employee performance leading to increase in organizational performance. The study was able to confirm the study of Jam \& Fathima (2006). The gap between this study and most studies on psychological contract is that most studies are on the breach of psychological contract neglecting the fulfillment aspect of the contract.

Secondly, Hypothesis one (H1); revealed a positive relationship between employees psychological contract fulfillment and employee's job satisfaction. This findings show that the more employers fulfill their side of the obligations, the more the employees will be happy (job satisfaction) and will be motivated to do more. This was also supported by the work of Rodwell et al. (2015) and that of Dogru, McGinley, Line and Szende (2019).

Hypothesis two (H2), showed a positive relationship between psychological contract fulfillment and organizational performance. This finding indicates that, the more organizations spend on their employees' psychological contract fulfillment the more successful it becomes. This is in line with Eugenio Proto of University of Bristol, UK, and IZA, Germany's report on Google workers, where it was reported that Google invested substantial amount on the well-being of their employee, which today is translating into performance for the company. The theory of Yalabik (2014) confirm that psychological contract have effect on organizational performance. It was also supported by the work of Huang, Huang, and Zhang (2019).

Hypothesis three (H3), showed a positive relationship between employee's job satisfaction and Organizational Performance. The findings revealed that the more employees are satisfied with their jobs, the more they will provide better services to the Satisfaction of their customers who will subsequently remain loyal to the company and spend more in buying product and service of such companies. This is in line with Cogsburn, Battaglion \& Bradbury (2014) suggestion. They explained that when conflicts are well managed, employees become satisfied in the company, leading to organizational performance. The work of Falola et al. (2018), Durst et al. (2018) and Wang and Lang (2019) also supported this hypothesis.

\section{Contributions}

This research contributes to industry and research related areas on psychological contract fulfillment and employee's job satisfaction on organizational performance. Concerning the industry players, the results of the study can potentially help businesses and other service providers better understand psychological contract fulfillment so that they can deal with their employees without any problem. The findings of the study indicate that when organizations are able to motivate and fulfill the psychological contracts of their employees, the employees are more likely to be committed to the organization and are satisfied with their jobs. To achieve successful empowerment, employee's perception about their supports from their organization/employers must be considered (Raub and Robert 2013). Thus, organizations must engage in delegations, interactions, employee well-being, engage employees in decision making to help increase employees perception of psychological contract fulfillment.

The research will also provide managers further evidence which will help them engage in good human relation practices and effective communication. It will help make clear expectations. Employees and employers will be able to make open communications about their expectations to avoid misunderstanding of the employment relationship. Practitioners, professionals, and researchers needs to explore the response of employees concerning psychological contract fulfillment from the developing country context.

\section{Conclusion and Implications}

This study paid attention to the effect of psychological contract fulfillment, employee's job satisfaction on organizational performance. Findings with regards to the psychological contract fulfillment, employee's job satisfaction in an organization shows that psychological contract fulfillment influences employee's job satisfaction, therefore neglecting the above variable will lead to a total dissatisfaction of employees which will lead to the collapse of an organization. It is very vital for management, shareholders and board of directors of companies to take into consideration psychological contract fulfillment as part of their pillar especially when dealing with Human resources management. Considering this can lead the organization to perform better, as in the case of Google, where the company invested so much to make the employees happy. Today, we all can attest to the fact that Google is one of the leading search engines in the world.

This study also revealed that psychological contract fulfillment influences organizational performance. What this means is that the more employers fulfill their side of the contract, employees will be satisfied and perform better on the job. Employees will thus be willing to do more for the organization, which will lead to better performance in 
terms of job performance and overall organizational performance.

Additionally, companies should find out about issues that affect employee's satisfaction and find ways of addressing them. Failure to do so would mean that employees would not commit themselves to the organization fully and would find excuses not to be productive. This would lead to underperformance by employees, which would have a negative effect on the performance of the organization.

\section{References}

Adhikari, H. P., Choi, W., \& Sah, N. B. (2017). That is what friends do: employee friendliness and innovation. Journal of Economics and Business, 90, 65-76. https://doi.org/10.1016/j.jeconbus.2016.10.004

Arthur, J. L., \& Kolson, M. F. (2017). Psychological contract fulfillment and its implication on performance of employees: The case of Asanko Gold Mine, Ghana. Journal of Public Administration and Policy Research, 9(2), 17-25.

Brikend, A. (2011). Job satisfaction. Management Research and Practices, 3(4), 77-86.

Bufquin, D., DiPietro, R., Orlowski, M., \& Partlow, C. (2017). The influence of restaurant co-workers' perceived warmth and competence on employees' turnover intentions: The mediating role of job attitudes. International Journal of Hospitality Management, 60, 13-22. https://doi.org/10.1016/j.ijhm.2016.09.008

Busser, J. A., Shulga, L. V., Kang, H. J., \& Ramirez Molintas, D. H. (2019). The effect of hospitality conference messaging on employee job responses. International Journal of Hospitality Management, 78, 284-292. https://doi.org/10.1016/j.ijhm.2018.09.011

Carter, S. P., Dudley, W., Lyle, D. S., \& Smith, J. Z. (2019). Who's the Boss? The effect of strong leadership on employee turnover. Journal of Economic Behavior \& Organization, 159, 323-343. https://doi.org/10.1016/j.jebo.2018.12.028

Chen, J., Leung, W. S., \& Evans, K. P. (2016). Are employee-friendly workplaces conducive to innovation? Journal of Corporate Finance, 40, 61-79. https://doi.org/10.1016/j.jcorpfin.2016.07.011

Chin, W. (2010). How to write up and report PLS analyses. In C. W. W. EspositoVinzi V, Henseler J, Wang H (Ed.), Handbook of partial least squares: concepts, methods and applications (pp. 655-690). Heidelberg: Springer.

Coetzee, M., \& Stoltz, E. (2015). Employees' satisfaction with retention factors: Exploring the role of career adaptability. Journal of Vocational Behavior, 89, 83-91. https://doi.org/10.1016/j.jvb.2015.04.012

Danica, B.(2016). Relationship between job satisfaction and organisational performance. Economic Research-Ekonomska Istraživanja, 29(1), 118-130. https://doi.org/10.1080/1331677X.2016.1163946.

Dogru, T., McGinley, S., Line, N., \& Szende, P. (2019). Employee earnings growth in the leisure and hospitality industry. Tourism Management, 74, 1-11. https://doi.org/10.1016/j.tourman.2019.02.008

Durst, P. T., Moore, S. J., Ritter, C., \& Barkema, H. W. (2018). Evaluation by employees of employee management on large US dairy farms. Journal of Dairy Science, 101(8), 7450-7462. https://doi.org/10.3168/jds.2018-14592

Escribá-Carda, N., Balbastre-Benavent, F., \& Teresa Canet-Giner, M. (2017). Employees' perceptions of high-performance work systems and innovative behaviour: The role of exploratory learning. European Management Journal, 35(2), 273-281. https://doi.org/10.1016/j.emj.2016.11.002

Falola, H. O., Oludayo, O. A., Olokundun, M. A., Salau, O. P., Ibidunni, A. S., \& Igbinoba, E. (2018). Employee resourcing strategies and universities' corporate image: A survey dataset. Data in Brief, 18, 1378-1382. https://doi.org/10.1016/j.dib.2018.04.006

Fornell, C., \& Larcker, D. F. (1981a). Evaluating structural equation models with unobservable variables and measurement error. Journal of Marketing Research, 18(1), 39-50.

Fornell, C., \& Larcker, D. F. (1981b). Evaluating structural equation models with unobservable variables and measurement error. Journal of Marketing Research, 18(1), 39-50.

Gould-Williams, J. (2003). The importance of HR practices and workplace trust in achieving superior.

Gurd, B., \& Helliar, C. (2017). Looking for leaders: 'Balancing' innovation, risk and management control systems. The British Accounting Review, 49(1), 91-102. https://doi.org/10.1016/j.bar.2016.10.008 
Hair Jr, J. F., Hult, G. T. M., Ringle, C., \& Sarstedt, M. (2016). A primer on partial least squares structural equation modeling (PLS-SEM). Sage publications.

Hair, J. F., Risher, J. J., Sarstedt, M., \& Ringle, C. M. (2019). When to use and how to report the results of PLS-SEM. European Business Review, 31(1), 2-24.

Hair, J., Ringle, C. M., \& Sarstedt, M. (2011). PLS-SEM: Indeed a Silver Bullet. Journal of Marketing Theory and Practice, 19(2), 139-151.

Hair, J., Ringle, C. M., \& Sarstedt, M. (2011). PLS-SEM: Indeed a Silver Bullet. Journal of Marketing Theory and Practice, 19(2), 139-151.

Henseler, J., Ringle, C. M., \& Sarstedt, M. (2015). A new criterion for assessing discriminant validity in variance-based structural equation modeling. Journal of the Academy of Marketing Science, 43(1), 115-135.

Ho, V., Rousseau, D., \& Levesque, L. (2006). Social networks and the psychological contract: Structured holes, cohesive ties, and beliefs regarding employer obligations. Human Relations, 59(4), 459-481. https://doi.org/10.1177/0018726706065370.

Hotchkiss, D. (2016). Governance and ministry: Rethinking board leadership: Rowman \& Littlefield.

Huang, P., Huang, H. Y., \& Zhang, Y. (2019). Do firms hedge with foreign currency derivatives for employees? Journal of Financial Economics, 133(2), 418-440. https://doi.org/10.1016/j.jfineco.2019.01.008

Ibrahim, R., Boerhannoeddin, A., \& Kazeem Kayode, B. (2017). Organizational culture and development: Testing the structural path of factors affecting employees' work performance in an organization. Asia Pacific Management Review, 22(2), 104-111. https://doi.org/10.1016/j.apmrv.2016.10.002

Jam, F. A., Haq, I. U., \& FatimaT. (2006). Psychological contract and job outcome: mediating role of affective commitment. Journal of management, 4(2), 13-25.

Jerrell D. Coggburn, R. Paul Battaglio Jr., Mark D. Bradbury, (2014). Employee job satisfaction and organizational performance: The role of conflict management. International Journal of Organization Theory \& Behavior, 17(4), 498-530. https:// doi.org/10.1108/IJOTB-17-04-2014-B005

Karagonlar, G., Eisenberger, R., \& Aselage, J. (2016). Reciprocation wary employees discount PCF. Journal of Organizational Behavior, 37, 23-40. https:// doi.org/10.1002 /job.2016

Krausert, A. (2017). HR differentiation between professional and managerial employees: Broadening and integrating theoretical perspectives. Human Resource Management Review, 27(3), 442-457. https://doi.org/10.1016/j.hrmr.2016.11.002

Latif, M. S., Ahmad, M., Qasim, M., Mushtaq, M., Ferdoos, A., \& Naeem, H. (2013). Impact of employee's job satisfaction on organizational performance. European Journal of Business and Management, 5(5), $166-171$.

Li, Z., \& Wu, M. (2018). Education and welfare program compliance: Firm-level evidence from a pension reform in China. China Economic Review, 48, 1-13. https://doi.org/10.1016/j.chieco.2017.08.014

Liu, C., Lin, B., \& Shu, W. (2017). Employee quality, monitoring environment and internal control. China Journal of Accounting Research, 10(1), 51-70. https://doi.org/10.1016/j.cjar.2016.12.002

Lomax, R. G., \& Schumacker, R. E. (2004). A beginner's guide to structural equation modeling. Psychology Press.

Messick, S. (1988). Validity. In R. L. Linn (Ed.), Educational Measurement (3rd ed.). New York, NY.: Macmillan.

Muls, A., Dougherty, L., Doyle, N., Shaw, C., Soanes, L., \& Stevens, A.-M. (2015). Influencing organisational culture: a leadership challenge. British Journal of Nursing, 24(12), 633-638.

Nguyen, L. T. V., Lu, V. N., Hill, S. R., \& Conduit, J. (2019). The mediating role of brand knowledge on employees' brand citizenship behaviour: Does organizational tenure matter? Australasian Marketing Journal (AMJ). https://doi.org/10.1016/j.ausmj.2019.04.003

Nishanthi, H. M., \& Mahalekamge, W. G. S. (2016). Impact of psychological contract on employee outcomes of job satisfaction and organizational commitment: evidence from a leading apparel manufacturing company in Sri Lanka. Kelaniya Journal of Human Resource Management, 11(2). 
Oludayo, O. A., Akanbi, C. O., Obot, B. M., Popoola, S. I., \& Atayero, A. A. (2018). Influence of talent retention strategy on employees' attitude to work: Analysis of survey data. Data in Brief, 20, 698-705. https://doi.org/10.1016/j.dib.2018.08.103

Pittino, D., Visintin, F., Lenger, T., \& Sternad, D. (2016). Are high performance work practices really necessary in family SMEs? An analysis of the impact on employee retention. Journal of Family Business Strategy, 7(2), 75-89. https://doi.org/10.1016/j.jfbs.2016.04.002

Raub, S., \& Robert, C. (2013). Empowerment, organizational commitment, and voice behavior in the hospitality industry: Evidence from a multinational sample. Cornell Hospitality Quarterly, 54(2), 136-148.

Ringle, C. M, Wende, S, \& Becker, J. M (Producer). (2015). SmartPLS 3. Retrieved from http://www.smartpls.com

Ringle, C. M., Wende, S., \& Becker, J. M. (Producer). (2015). SmartPLS 3. Retrieved from http://www.smartpls.com Ringle, C.M, Wende, S, \& Becker, J.M (Producer). (2015). "SmartPLS 3". Retrieved from http://www.smartpls.com

Rodwell, J., Ellershaw, J., \& Flower, R. (2015). Fulfill psychological contract promises.

Rodwell, J., Ellershaw, J., \& Flower, R. (2015). Fulfill psychological contract promises.

Salem, I. E. B., \& Abdien, M. K. (2017). Implementation of employee cross-training during perilous conditions in hotels. Tourism Management Perspectives, 23, 68-74. https://doi.org/10.1016/j.tmp.2017.05.005

Schumacker, R. E. (2017). Interaction and nonlinear effects in structural equation modeling. Routledge.

Spasojevic, B., Lohmann, G., \& Scott, N. (2019). Leadership and governance in air route development. Annals of Tourism Research, 78, 102746. https://doi.org/10.1016/j.annals.2019.102746

Stamolampros, P., Korfiatis, N., Chalvatzis, K., \& Buhalis, D. (2019). Job satisfaction and employee turnover determinants in high contact services: Insights from Employees'Online reviews. Tourism Management, 75 , 130-147. https://doi.org/10.1016/j.tourman.2019.04.030

Suh, J. B., Shim, H. S., \& Button, M. (2018). Exploring the impact of organizational investment on occupational fraud: Mediating effects of ethical culture and monitoring control. International Journal of Law, Crime and Justice, 53, 46-55. https://doi.org/10.1016/j.ijlcj.2018.02.003

Turnea, E. S. (2018). Attraction and Retention of the Employees. A Study based on Multinationals from Romania. Procedia - Social and Behavioral Sciences, 238, 73-80. https://doi.org/10.1016/j.sbspro.2018.03.009

Vuori, J., Törnroos, K., Ruokolainen, M., \& Wallin, M. (2019). Enhancing late-career management among aging employees - A randomized controlled trial. Journal of Vocational Behavior, 103327. https://doi.org/10.1016/j.jvb.2019.103327

Wang, Y. C., \& Lang, C. (2019). Service employee dress: Effects on employee-customer interactions and customer-brand relationship at full-service restaurants. Journal of Retailing and Consumer Services, 50, 1-9. https://doi.org/10.1016/j.jretconser.2019.04.011

Yalabik, B. A. (2014). Work engagement, psychological contract breach and job satisfaction.

\section{Copyrights}

Copyright for this article is retained by the author(s), with first publication rights granted to the journal.

This is an open-access article distributed under the terms and conditions of the Creative Commons Attribution license (http://creativecommons.org/licenses/by/4.0/). 